\title{
The collation of forensic DNA case data into a multi-dimensional intelligence database
}

\author{
SJ Walsht, DS Moss ${ }^{*}$ C Kliem and GM Vintiner \\ Institute of Environmental Science and Research Ltd., Private Bag 92 021, Auckland, New Zealand \\ Science \& Justice 200242205 - 214 Received 21 January 2002 accepted 17 June 2002
}

The primary aim of any DNA Database is to link individuals to unsolved offences and unsolved offences to each other via DNA profiling. This aim has been successfully realised during the operation of the New Zealand (NZ) DNA Databank over the past five years. The DNA Intelligence Project (DIP), a collaborative project involving $\mathrm{NZ}$ forensic and law enforcement agencies, interrogated the forensic case data held on the NZ DNA Databank and collated it into a functional intelligence database. This database has been used to identify significant trends which direct Police and forensic personnel towards the most appropriate use of DNA technology. Intelligence is being provided in areas such as the level of usage of DNA techniques in criminal investigations, the relative success of crime scene samples and the geographical distribution of crimes. The DIP has broadened the dimensions of the information offered through the NZ DNA Databank and has furthered the understanding and investigative capability of both Police and forensic scientists. The outcomes of this research fit soundly with the current policies of 'intelligence led policing', which are being adopted by Police jurisdictions locally and overseas.

Le premier but de toute base de données ADN est de lier des individus à des délits non résolus et des délits non résolus entre eux par le biais de l'ADN. Ce but a été réalisé avec succès durant la mise en oeuvre de la base de données néo zélandaise sur les cinq dernières années. Le projet de renseignement ADN (DIP), un projet de collaboration entre les agences de polices et laboratoires forensiques de Nouvelle Zélande a permis d'étudier les dossiers forensiques détenus par la base de données ADN de Nouvelle Zélande et les a réuni dans une base de données de renseignements fonctionnelle. Cette base de données a été utilisée pour identifier des tendances significatives qui dirigent la police et le personnel forensique vers l'application la plus appropriée de la technologie ADN. Le renseignement est apporté dans des domaines tels que le niveau de l'utilisation des techniques ADN dans les investigations criminelles, les succès relatifs des échantillons provenant de scènes de crimes et la répartition géographique des crimes. Le DIP a élargi les dimensions de l'information offerte à travers la base de données ADN de Nouvelle Zélande et a amélioré la compréhension de la capacité investigatrice de la police et des spécialistes forensiques. II ressort de cette recherche qu'elle correspond parfaitement avec la politique actuelle de policing conduite par le renseignement qui est adoptée dans les circonscriptions de police, localement et à l'étranger.

*Author for correspondence: Currently Forensic Alliance Ltd, F5 Culham Science Centre, Abingdon, Oxfordshire OX14 3ED, United Kingdom tCurrent address Centre for Forensic Science, University of Technology Sydney, PO Box 123, Broadway, NSW 2007, Australia
Das urspruengliche Ziel einer jeden DNA-Datei ist, mittels eines DNA-Profils einen Zusammenhang zwischen unaufgeklaerten Kriminalfaellen und bestimmten Personen, sowie zwischen mehreren Kriminalfaellen herzustellen. Dieses Ziel wurde innerhalb von fuenf Jahren mit der Neuseelaendischen (NZ) DNA Datenbank erreicht. Das "DNA Intelligence Project (DIP)", eine Kooperation zwischen neuseelaendischen Ermittlungs - und Strafverfolgungsbehoerden, untersuchte Ermittlungsergebnisse, die in der NZ-Datenbank enthalten waren und fasste diese Erkenntnisse in einer funktionierenden Ermittlungsdatenbank zusammen. Diese Datenbank wurde benutzt, um Polizei und Ermittlungsbehoerden eine moeglichst effiziente Nutzung der DNA Technologie zu ermoeglichen. Die Datenbank liefert Erkenntnisse aus verschiedenen Gebieten, so zum Beispiel, bis zu welchem Grade DNA Technologie eingesetzt werden kann, welches die relative Erfolgsrate von Proben von verschiedenen Tatorten ist und listet die geographische Verteilung von Straftaten. DIP hat das Informationsangebot der NZ DNA-Datenbank erweitert und traegt wesentlich zur Erhoehung des Verstaendnisses und der Ermittlungskapazitaet von sowohl Polizei als auch Strafermittlungsbehoerden bei. Das Ergebnis dieser Forschung fuegt sich nahtlos mit der momentanen Auffassung einer "Intellegenten Polizeiarbeit", die sowohl lokal als auch im Ausland mehr und mehr zur Anwendung kommt.

La finalidad primaria de cualquier base de datos del ADN es relacionar individuos con delitos no resueltos y delitos no resueltos entre sí a través de los perfiles de ADN. Esta finalidad ha sido ampliamente realizada con éxito por el banco de datos de ADN de Nueva Zelanda (NZ) durante su trabajo de los pasados 5 años. El proyecto de Inteligencia del ADN (DIP), un proyecto en colaboración con las agencias forense y de policía de NZ, tomaba los datos de casos forenses guardados en la base de datos de NZ y los relacionaba con las bases de datos funcionales de la policía. Esta base de datos se ha usado para identificar tendencias significativas que dirijan a la policía y personal forense hacia un uso más apropiado de la tecnología del ADN. La información se proporciona en áreas tales como el nivel de uso de las técnicas de ADN en investigaciones criminales, el éxito relativo de las muestras del escenario del crimen y la distribución geográfica de los crímenes. El DIP ha ensanchado las dimensiones de la información ofrecida a través del banco de datos de ADN de NZ y ha mejorado el entendimiento y capacidad investigadora de la policía y de los científicos forenses. Los resultados de esta investigación encajan perfectamente con las políticas actuales de "políticas de inteligencia guiada" que están siendo adoptadas por las jurisdicciones de policía tanto locales como internacionales.

(C) The Forensic Science Society 2002

Key words Forensic science, DNA intelligence project, DNA database, intelligence led policing, crime trends. 


\section{Introduction}

In August 1996, the NZ DNA Databank began operations following the enactment of the Criminal Investigations (Blood Samples) Act, 1995 (CIBS Act) [1]. Over the subsequent five years the anticipated impact on forensic investigation has been successfully realised [2]. The CIBS Act has proven a robust and effective legislative tool [3] and in combination with the SGM Plus “ [4] short tandem repeat (STR) DNA profiling systems provide the foundation for DNA Databank operations. This relatively new form of forensic DNA analysis has led to the detection of crime-to-person links in over 1654 unsolved offences and the provision of valuable intelligence in a further 1282 cases through the detection of crime-to-crime links.

The volume of analytical work associated with a DNA Database can introduce significant operational changes to a forensic organisation [5]. In NZ, the Institute of Environmental Science and Research Ltd (ESR) provides forensic services in crime scene investigation, DNA profiling, illicit drugs, clandestine laboratories, physical evidence and toxicology. Unsolved crimes for the specific purpose of DNA Databank comparison now comprise over $40 \%$ of all forensic cases submitted to the ESR. In the period July 2001 to June 2002 , submissions are anticipated to be in excess of 2500 cases. Similar trends presented by forensic service providers in the United Kingdom (UK) [6,7], the United States [8] and Europe [9] demonstrate similarly staggering figures. Coping with such high volumes of work requires streamlining of the analytical processes, the implementation of computerised database systems (such as the Forensic Evidence Database System - FoRED, designed and built by the ESR) and absolute adherence to the governing legislative and quality assurance requirements.

Perhaps a more significant alteration to the focus of the forensic scientist, brought about by the requirements of DNA databasing, is the removal of the traditional precondition of examining a single case before advancing to the next one. Although each individual case is still given due attention, high throughput processing of DNA Database cases requires a collective approach. This is understandable, as without the DNA profiles from other cases and the individual donors, analysis of a lone case becomes somewhat superfluous. As the databases grow, they themselves can become the focus of forensic and lawenforcement attention and a potential source of intelligence information.

Following the establishment of the NZ DNA Databank, consideration was given as to whether examination of other features of the database (aside from its primary function of comparing DNA profiles) could yield intelligence data relevant to the management and use of this technology. Of importance also was a means to incorporate the collation, analysis and distribution of such information into the routine functions of the DNA Databank. The DIP was initiated in 1999 to address these questions. It aimed to create a repository of data from DNAbased cases, which had not previously been collated, and distribute the key outcomes of the analysis of this data to the NZ law enforcement community.
The information was entered into an independent database which was customised to analyse trends and report key findings. The case data was examined at three fundamental levels in an attempt to identify trends and variances impacting on the overall effectiveness and use of the DNA Databank. The basic levels examined were: submission trends, analytical trends, and match trends.

Significant findings in areas such as the usage of DNA in criminal investigations, the relative success of crime scene samples and the geographical distribution of crimes have been obtained from the DIP identifying, in some cases, areas where the effectiveness of the DNA Databank could be enhanced. Where relevant, data obtained from the DIP has been compared to published criminal justice outcomes and considered in this broader context. Preliminary outcomes of this project indicate that valuable intelligence can be contributed through quantitative analysis of forensic case data and areas for future investigation have been identified. In our opinion, such intelligence mining of forensic DNA case data represents an under-utilised approach to the use of forensic science in law enforcement strategy. This research is encompassed by the broader concept referred to as 'intelligence led policing', now an accepted focus for international law enforcement agencies [10].

\section{Methods}

The NZ DNA Databank comprises two distinct databases, the National DNA Database (NDD), which holds DNA profile information from convicted offenders and volunteer donors, and the Crime Sample Database (CSD), which holds DNA profile information from criminal investigations. Comparisons are routinely made within and between each database to identify crime-to-person or crime-to-crime links, referred to as 'matches'. Person-to-person matches within the NDD are also performed and reviewed to identify duplicate profiles on the NDD. Due to the small population of NZ and the single police force, all duplicates are investigated and spurious NDD profiles (such as those originating from a sample given under an alias) are removed.

The DIP contains information from all submissions to the NZ DNA Databank between August 1996 and June 2001. Most analysis of this data has been undertaken at a Police District level (there are twelve Police Districts in NZ). To maintain anonymity, Police Districts have been referred to by a designated letter rather than by name (unprotected data can be obtained by a request to the Office of the National Crime Manager, NZ Police). Selected data relating to the offences stored on the CSD were combined into a Microsoft" Access 97 database package, tracked by a unique sample barcode. The reporting function of the software was used to customise extraction of desired information from the database. The information has been combined into a summary report which is updated and distributed monthly to senior Police personnel.

\section{Results}

The growth and success of the NZ DNA Databank over the past five years is illustrated in Table 1. Previous publications have 
Table 1 Summary of the growth and effectiveness of the NZ DNA Databank.

\begin{tabular}{lccccc} 
& \multicolumn{5}{c}{ Cumulative Total } \\
Date (June) & $\mathbf{1 9 9 7}$ & $\mathbf{1 9 9 8}$ & $\mathbf{1 9 9 9}$ & $\mathbf{2 0 0 0}$ & $\mathbf{2 0 0 1}$ \\
\hline $\begin{array}{l}\text { National DNA Database } \\
\text { (Individuals on DNA Databank) }\end{array}$ & 1,331 & 5,137 & 8,854 & 13,488 & 18,101 \\
$\begin{array}{l}\text { Crime Sample Database } \\
\text { (Crimes on DNA Databank) }\end{array}$ & - & 21 & 687 & 1,313 & 2,677 \\
$\begin{array}{l}\text { 'Match' rate } \\
\text { (crime to person) }\end{array}$ & - & $9.5 \%$ & $39.2 \%$ & $39.8 \%$ & $36.9 \%$ \\
$\begin{array}{l}\text { 'Match' rate } \\
\text { (crime to crime) }\end{array}$ & - & & & & \\
\hline
\end{tabular}

Table 2 Overall submissions of case samples and reference bloods to the NZ DNA Databank.

\begin{tabular}{lrrrrrrrrrrrr} 
Police & \multicolumn{9}{c}{ Submission of NDD Reference Samples } & \multicolumn{4}{c}{ Submission of CSD Cases } \\
District & $\mathbf{1 9 9 7}^{*}$ & $\mathbf{1 9 9 8}$ & $\mathbf{1 9 9 9}$ & $\mathbf{2 0 0 0}$ & $\mathbf{2 0 0 1}$ & Total & Rate & 1999 & $\mathbf{2 0 0 0}$ & $\mathbf{2 0 0 1}$ & Total & Rate \\
\hline A & 228 & 515 & 835 & 585 & 592 & 2755 & 7.96 & 354 & 215 & 507 & 1076 & 3.11 \\
B & 64 & 294 & 318 & 373 & 367 & 1416 & 6.30 & 81 & 46 & 165 & 292 & 1.30 \\
C & 197 & 298 & 292 & 247 & 297 & 1331 & 2.84 & 63 & 98 & 211 & 372 & 0.79 \\
D & 71 & 327 & 318 & 484 & 294 & 1494 & 4.45 & 53 & 89 & 139 & 281 & 0.84 \\
E & 159 & 236 & 321 & 545 & 759 & 2020 & 6.87 & 204 & 133 & 308 & 645 & 2.19 \\
F & 56 & 149 & 119 & 277 & 327 & 928 & 4.92 & 38 & 19 & 85 & 142 & 0.75 \\
G & 69 & 272 & 183 & 425 & 585 & 1534 & 4.68 & 166 & 85 & 358 & 609 & 1.86 \\
H & 183 & 861 & 679 & 575 & 465 & 2763 & 20.16 & 128 & 59 & 70 & 257 & 1.88 \\
I & 99 & 115 & 91 & 188 & 223 & 716 & 2.54 & 20 & 11 & 149 & 180 & 0.57 \\
J & 1 & 23 & 37 & 76 & 160 & 297 & 1.99 & 4 & 5 & 14 & 23 & 0.15 \\
K & 46 & 163 & 131 & 188 & 186 & 714 & 2.04 & 37 & 45 & 90 & 172 & 0.49 \\
L & 74 & 535 & 393 & 671 & 358 & 2031 & 4.91 & 94 & 119 & 237 & 450 & 1.09 \\
Average & 104 & 316 & 310 & 386 & 384 & 1500 & 6 & 104 & 77 & 194 & 375 & 1
\end{tabular}

*This date range encompasses the period from the beginning of Databank operations in August 1996 to 30 June 1997. All subsequent dates are yearly totals taken at the end of each financial year.

**Indexed submission rate (overall number of submissions per 1000 population).

examined these and other aspects of the NZ DNA Databank $[2,11]$.

\section{Submission Trends}

The volume and nature of submissions to the NZ DNA Databank has been examined to provide a basic index of utilisation by Police Districts. Submissions of reference blood samples for inclusion on the NDD have steadily increased since 1996 and presently average approximately 400 samples per month. It is anticipated in the near future the submission rate will increase further due in part to a proposed amendment to the $\mathrm{CI}(\mathrm{BS})$ Act
[1], which will allow the inclusion of DNA profiles from buccal swabs on the DNA Databank [12]. There is an obvious distinction across Police Districts in the volume of NDD samples submitted (Table 2).

To allow comparison the data was indexed into a submission rate, calculated by the number of NDD samples submitted per 1000 population. Examination of the indexed submission rate (Figure 1) shows differences exist in the utilisation of the NDD across NZ, with a factor of ten separating the highest and lowest submission rates between extreme Police Districts. The high 
Figure 1 Comparison of DNA Databank submission rates across Districts and to the national average.

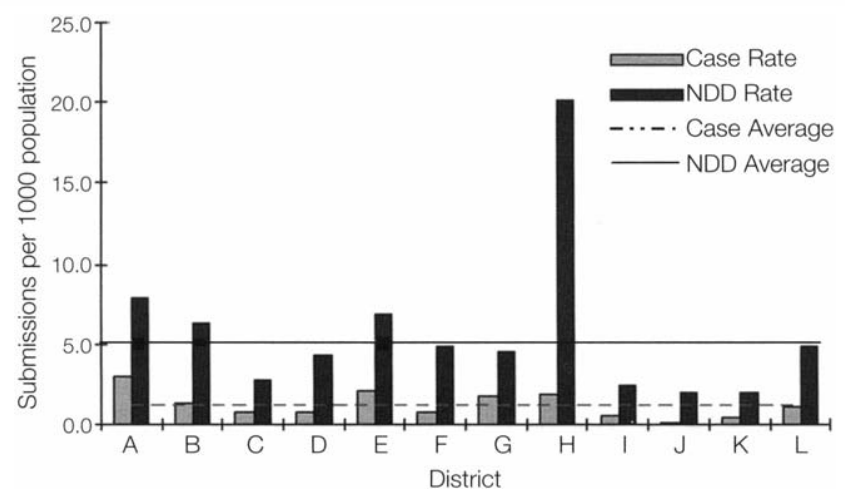

submission rate of District $\mathrm{H}$ is correlated with a specific policy decision to focus resources on obtaining NDD samples. Conversely, some regions (J, K) have reduced submission rates when compared with other Districts and the national average of 5.8 samples submitted per 1000 population.

The number of unsolved crimes submitted for DNA analysis and subsequent inclusion on the CSD has increased steadily since the inception of CSD sample analysis in mid-1998. Indexed case submission data shows broad variation across Districts with disparity between the highest and lowest Districts approximately a factor of twenty. Districts on or exceeding the national average for case submissions ( $\mathrm{A}, \mathrm{B}, \mathrm{E}, \mathrm{G}$ and $\mathrm{H}$ ) also tend to be above the national average for NDD submissions. Similarly, Districts that submit a low volume of cases are the same Districts that submit a low number of NDD samples.

Property offences, including burglary, arson and car theft, are the most frequently submitted offence category. Collectively, property offences make up over $80 \%$ of overall submissions (Table 3). The prevalence of these crimes, and the fact that there is rarely a suspect for Police questioning, means that DNA analysis provides a valuable means for linking an individual or other offences with the crime in question. Violent offences, including sexual assault, abduction, aggravated robbery and homicide, comprise over $12 \%$ of overall submissions. The remaining submissions are comprised of a small number of antisocial offences, such as drug offences, other offences against the person and miscellaneous offence types.

Variation in the number of cases submitted by different Districts is obvious from Table 3 , although first appearances can be slightly misleading. The combined proportion of the two most common offence types submitted from each District gives a more accurate indication of the submission profile. Some Districts submit across almost the full range of offences measured (A, B, C and G) whereas others submit fewer offence types $(\mathrm{J})$. Examining the profile of submissions from different Districts shows that for all Districts burglary is the most
Figure 3 The net submissions of both NDD and CSD samples show a high correlation with the crimeto-person match rate.

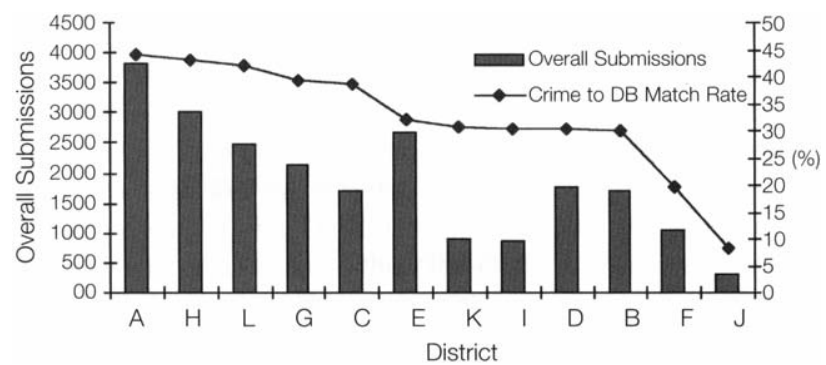

commonly submitted offence type (between $64.5 \%$ and $77.3 \%$ ) followed by either sexual assault (3.4\% to $12.9 \%)$ or car theft (3.7\% to $23.9 \%$ ). The submission profile of a District may represent its crime profile or submission policy regarding the use of the DNA Databank for investigative purposes.

As the application of forensic DNA databases becomes a more global reality there has also been a small but increasing number of international cases recently submitted for comparison. At present approximately 2-4 cases per month are received from Interpol mostly in relation to unsolved homicides or serial crimes originating from Europe.

\section{Analytical Trends}

Examining some of the investigative aspects involved in the application of DNA profiling to unsolved crimes is a means of assessing features such as the success and scope of the crime scene investigation and the strengths and weaknesses of the laboratory techniques. The case data ( $>4,500$ cases) was segregated by evidence type. A working assumption was made that the distribution of evidence types in the data will approximate the frequency at which they would each be expected at these types of crime scenes. Some exceptions occur when considering certain evidence types such as semen which is usually associated with sexual assaults. Given this, it follows that in the absence of a selective submission policy, the distribution of evidence types submitted to the CSD should be similar across Districts. Based on this working assumption, comparison was made between the distribution of evidence types from each District (Figure 2). Districts with a low submission for a given sample type may be operating a selective submission policy (due to budget constraints for example) or they may be overlooking evidence of that type during the crime scene investigation. Conversely, unusually high submissions for a given evidence type implies that other evidence types may be being overlooked or that particular evidence is favoured or submitted selectively.

The most notable differences are among the drinking vessels 
Table 3 Distribution of cases submitted by offence type for each of the NZ Police Districts. Crime-to-person matches have been abbreviated to $\mathrm{C} / \mathrm{P}$ and crime-to-crime matches to $\mathrm{C} / \mathrm{C}$. The column 'Load' indicates the number of profiles which have been successfully loaded to the CSD.

\begin{tabular}{|c|c|c|c|c|c|c|c|c|c|c|c|c|c|c|c|}
\hline District & Cases $^{*}$ & Abdct & $\begin{array}{r}\text { Agg } \\
\text { Robb }\end{array}$ & Arson & Assit & Burg & Drugs & Homic & Misc & $\begin{array}{l}\text { Sex } \\
\text { Assit }\end{array}$ & $\begin{array}{l}\text { Car } \\
\text { Theft }\end{array}$ & Other & Load & $\begin{array}{l}\text { C/P } \\
(\%)\end{array}$ & $\begin{array}{l}\text { C/C } \\
\text { (\%) }\end{array}$ \\
\hline A & 1035 & 5 & 46 & 5 & 9 & 790 & 0 & 7 & 6 & 45 & 115 & 7 & 635 & 44.3 & 41.3 \\
\hline B & 278 & 9 & 9 & 5 & 1 & 182 & 2 & 4 & 5 & 32 & 26 & 3 & 170 & 30.6 & 15.3 \\
\hline C & 358 & 0 & 4 & 3 & 4 & 269 & 3 & 21 & 6 & 30 & 14 & 4 & 230 & 39.6 & 26.5 \\
\hline$D$ & 274 & 0 & 8 & 6 & 3 & 204 & 0 & 3 & 1 & 17 & 29 & 3 & 183 & 30.1 & 25.1 \\
\hline$E$ & 617 & 0 & 26 & 5 & 16 & 398 & 1 & 0 & 3 & 53 & 112 & 3 & 463 & 32.6 & 28.9 \\
\hline$F$ & 138 & 3 & 8 & 0 & 4 & 89 & 0 & 6 & 6 & 12 & 9 & 1 & 83 & 20.5 & 10.8 \\
\hline $\mathrm{G}$ & 592 & 2 & 49 & 8 & 6 & 406 & 0 & 1 & 7 & 20 & 85 & 8 & 325 & 40.0 & 36.9 \\
\hline $\mathrm{H}$ & 251 & 0 & 2 & 2 & 3 & 170 & 1 & 0 & 3 & 9 & 60 & 1 & 131 & 43.5 & 19.8 \\
\hline 1 & 180 & 0 & 2 & 3 & 3 & 128 & 1 & 0 & 5 & 7 & 29 & 2 & 108 & 31.5 & 13.9 \\
\hline$J$ & 22 & 0 & 1 & 0 & 0 & 17 & 0 & 0 & 1 & 2 & 1 & 0 & 12 & 8.3 & 0 \\
\hline $\mathrm{K}$ & 163 & 0 & 5 & 1 & 13 & 108 & 0 & 3 & 2 & 21 & 6 & 4 & 91 & 31.9 & 24.2 \\
\hline L & 427 & 0 & 12 & 3 & 6 & 293 & 0 & 10 & 4 & 40 & 56 & 3 & 252 & 42.1 & 22.6 \\
\hline Total & 4335 & 19 & 172 & 41 & 68 & 3054 & 8 & 55 & 49 & 288 & 542 & 39 & 2683 & - & - \\
\hline$\%$ of total & 100 & 0.4 & 4.0 & 0.9 & 1.6 & 70.4 & 0.2 & 1.3 & 1.1 & 6.6 & 12.5 & 0.9 & 61.8 & - & \\
\hline
\end{tabular}

*Cases received without specified offence types are labelled 'unknown' in the database. These cases have not been included in this section so the total numbers may differ slightly from those reported earlier.

data, where distribution ranges from $0 \%$ (District $\mathrm{J}$ ) to $22 \%$ (District I) against a national average of $9 \%$. As drinking vessels are a relatively diverse evidence type and one which has shown a recent increase in overall submissions [13], it is possible that some Districts are overlooking them at crime scenes.

A summary of the laboratory success rate and Databank match rates for each type of sample is presented in Table 4. Of particular interest are the relatively high crime-to-crime match rates for the more diverse sample types such as cigarette butts, drinking vessels, saliva stains and 'trace' evidence (which mostly includes samples from discarded clothing and swabs from vehicles and objects associated with the alleged offence) and the below average match rates for DNA profiles loaded from semen samples. The success of the less obvious evidence types reinforces the need for crime scene examiners to be aware of the analytical potential of DNA so all available potential evidence is utilised. The measure of analytical success also provides Police with a hierarchy of most suitable evidence types if they are faced with multiple options and are required to prioritise submissions.

\section{Match Trends}

Examining trends relating to DNA Databank 'matches' allows us to reflect on the overall effectiveness of this particular type of forensic analysis as a crime-solving tool. It also provides a means of surveying the data from a criminological perspective.

The crime-to-person match rate is the number of crime-to-person matches over the number of cases loaded to the CSD and therefore measures the proportion of loaded cases which are linked to an individual (Table 3). Five Districts (A, C, G, H, L) have a crime-to-person match rate above the national average of $37 \%$, five Districts (B, D, E, I, K) have a below average match rate of 30-32\% and two Districts ( $\mathrm{F}$ and $\mathrm{J}$ ) have a match rate of less than $20 \%$. Several factors were examined for potential effect on the crime-to-person match rate, including volume and indexed rate of submissions of NDD and CSD samples and ratio of NDD to CSD samples. The most profound effect on a specific 
Figure 2 Six major evidence types submitted by NZ Police Departments. Hair and other bodily samples have been excluded as they make up less than $5 \%$ of all evidence. The sample category 'drinking vessels' encompasses samples collected from bottles, cans and glasses thought to have been used by the offender, whilst the 'saliva' category includes samples such as spit and stains on balaclavas.
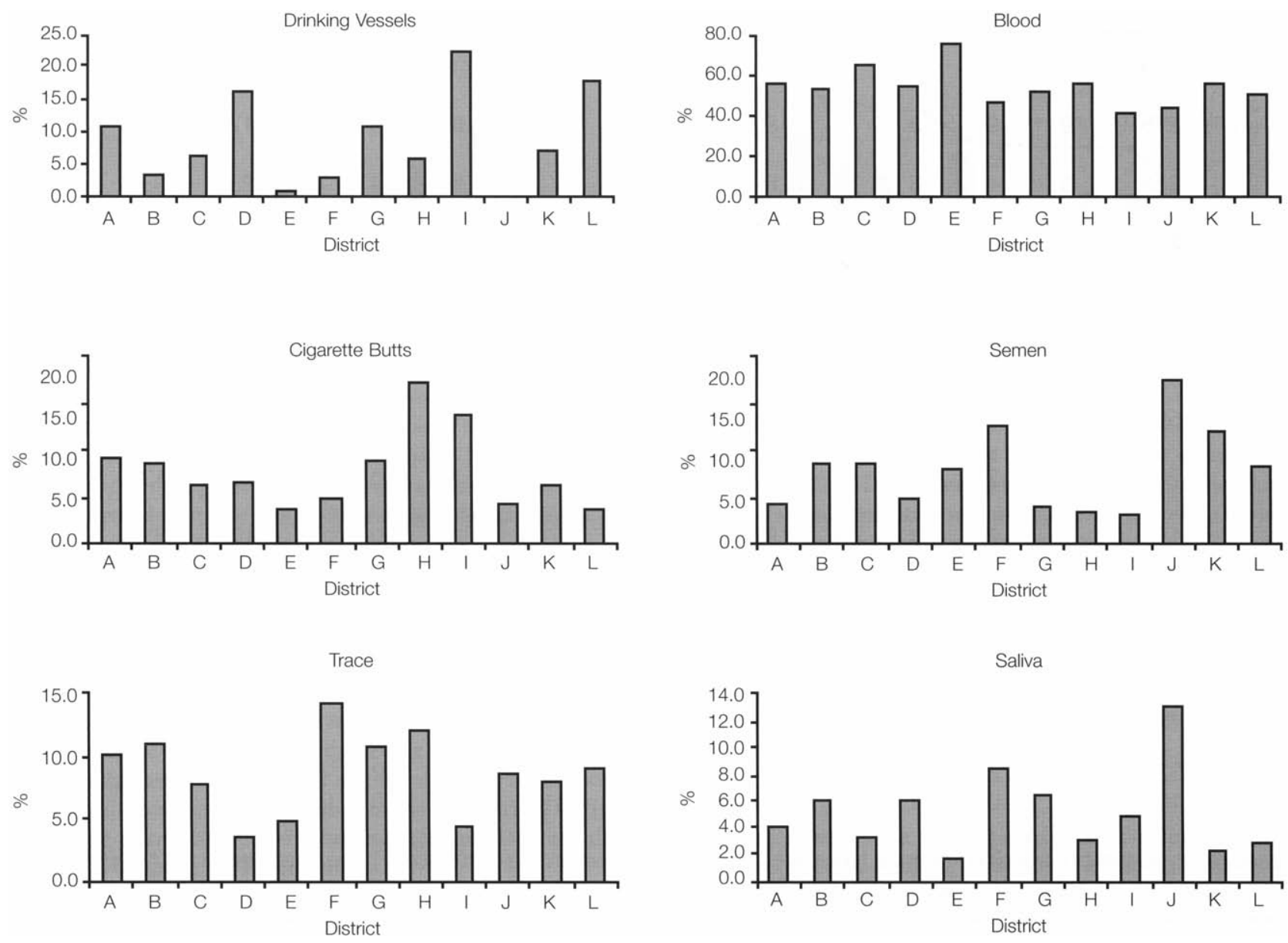

Table 4 Summary of laboratory and databank success rates for each major evidence type.

\begin{tabular}{lccccc}
$\begin{array}{l}\text { Sample } \\
\text { Type }\end{array}$ & $\begin{array}{c}\text { No. } \\
\text { Submitted }\end{array}$ & $\begin{array}{c}\text { No. } \\
\text { Loaded }\end{array}$ & $\begin{array}{c}\text { Success Rate } \\
\text { (\%) }\end{array}$ & $\begin{array}{c}\text { Crime-to-Person } \\
\text { Match Rate (\%) }\end{array}$ & $\begin{array}{c}\text { Crime-to-Crime } \\
\text { Match Rate (\%) }\end{array}$ \\
\hline Blood & 2565 & 1861 & 72.5 & 39.9 & 40.2 \\
Semen & 294 & 213 & 72.4 & 27.2 & 10.8 \\
Cig Butt & 352 & 175 & 49.7 & 37.71 & 49.71 \\
Bottle Swab & 441 & 184 & 41.7 & 33.15 & 47.83 \\
Saliva & 224 & 91 & 40.6 & 36.26 & 50.55 \\
'trace' & 387 & 89 & 23 & 35.96 & 43.82 \\
Hair & 159 & 26 & 16.4 & 26.92 & 30.77 \\
\hline
\end{tabular}


District's crime-to-person match rate was found to be the net volume of NDD and CSD samples submitted, as demonstrated in Figure 3. This is in contrast with findings of other forensic service providers who have reported optimum submission ratios and levels [14].

The crime-to-crime match rate is the number of crime-to-crime matches over the number of cases loaded to the CSD and measures the proportion of cases that match at least one other crime. Three Districts (A, E, G) have an above average crime-tocrime match rate of $28 \%$. All are from predominantly urban areas associated with NZ's largest city, and have submitted the largest total numbers of cases, possibly explaining the propensity for linked crimes.

The distribution of crime-to-person matches by offence type mirrors the distribution of cases submitted. The number of matches for the major offence types submitted, burglary $(76 \%)$, vehicle theft $(12 \%)$ and sexual assault $(6 \%)$, are approximately equal to their submission rates $(70 \%, 13 \%$ and $7 \%$ respectively). Other case types considered in this project collectively made up the remaining $6 \%$ of crime-to-person matches.

The crime-to-person match rates as calculated for each offence type (for example the proportion of burglaries loaded to the CSD that match a person on the NDD) demonstrates variation between categories (Figure 4). Property offences (burglary and vehicle theft) have a higher match rate than more violent offences (sexual assault and homicide). This could be linked with the volume of submissions but does not correspond with expected trends from criminological data [15].

The most recent phase of this project has involved analysing the geographic distribution of offences and evaluating any relationships between localities with the aid of geographical information system (GIS) mapping. The most useful aspect of this application will probably exist at the station or area level, however early consideration of District trends has demonstrated some interesting features and provided useful intelligence (Figure 5). Linking of individuals with crimes outside their 'home' jurisdiction allows Police in a given location to identify other Districts or Areas which may act as sources of offenders.

Figure 4 The crime-to-person match rate calculated for individual offence types. The lower than average match rate for sexual offences and homicides were unexpected.

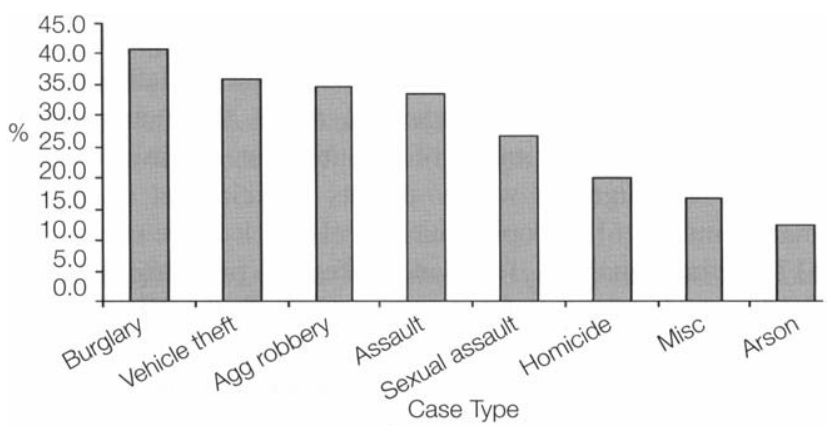

Figure 5 Geographical distribution of crime-to-person matches from two NZ Police Districts.

\section{Percentage of Hits $0 \%$ $1 \%-5 \%$ $5 \%-10 \%$ $10 \%-20 \%$ $20 \%-50 \%$ $>50 \%$}
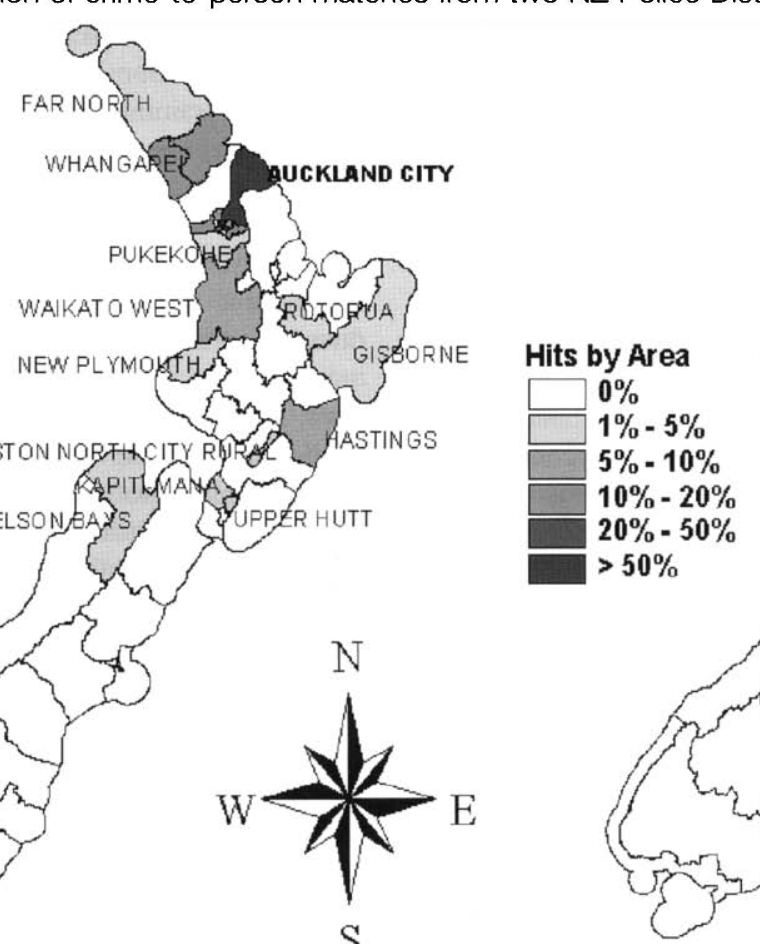

$>50 \%$ 400 Miles

0

200

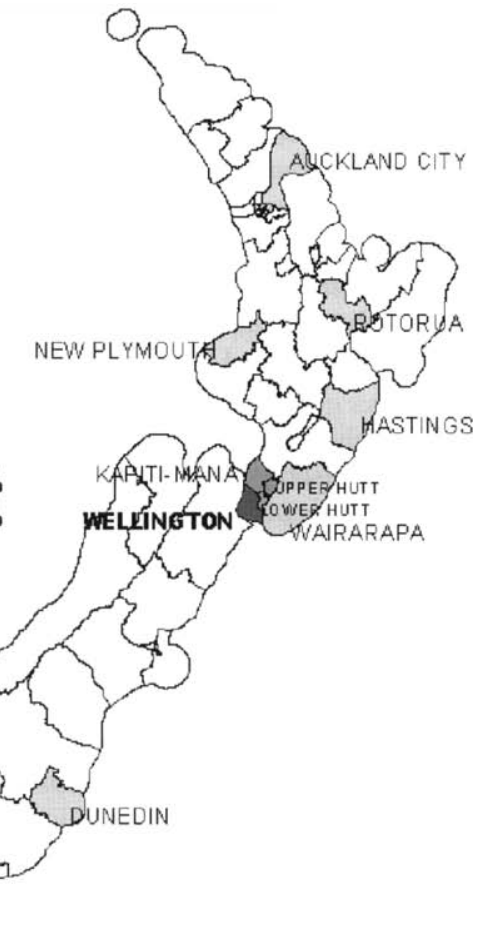


Examination of the NDD samples linked to crimes committed in the Auckland City area demonstrates that the samples have reasonably dispersed origins. Although, as expected, most samples were collected in Auckland City itself, a significant number of samples originate from other areas across the country with a relationship existing between offenders from Hastings, Whangarei, Waikato West and South Auckland compared to other (often geographically more closely related) areas. Conversely, NDD samples linked to crimes in the Wellington City generally originate from either Wellington City or its immediate surrounds.

\section{Discussion}

When the NZ DNA Databank began operation in 1996, the initial challenge was to establish a robust system that would enhance the crime-solving potential of the law enforcement and forensic communities. The research initiated through the DIP shows the DNA Databank now has the capacity to be put to a more comprehensive use as an intelligence tool by examining the forensic case data stored by virtue of its existence. 'Intelligence led policing' is a much-used contemporary term relating to law enforcement strategy. In practical terms there are recent examples of the utilisation of scientific or forensic data to provide intelligence which directs policing at both the management [16] and operational levels, such as the use of GIS [17], crime analysis [18] and offender profiling [19]. A fundamental objective of this project was to further illustrate the potential of forensic science data, in particular data from DNA based cases, to have a positive influence on aspects of law enforcement strategy.

\section{Submission Trends}

The predominant finding following examination of submission data for both the NDD and the CSD is that the volume of samples is a critical factor. The regions that submit the most reference samples and unsolved crimes to the DNA Databank are receiving the greatest returns as measured by match rates. This finding supports tactical decisions, such as that made by District $\mathrm{H}$, to submit as many NDD samples as the legislation and local resources allow. The result of this heavy investment of Police resources has been a crime-to-person match rate which has consistently remained over $42 \%$.

The NZ Police released crime figures for the year ending June 2001 which showed an increase in the resolution rate for burglaries from $14.3 \%$ to $17.2 \%$. This was due mainly to a large drop in the number of recorded burglaries and maintenance of previous numbers of crimes resolved [20]. Resolution rate is calculated by establishing the number of resolved offences with respect to the total number of reported offences. Applied to CSD cases, the resolution rate for burglaries submitted for DNA analysis is $24.8 \%$ (number of crime-to-person matches for burglary/number of burglaries submitted). This crude algorithm excludes resolution through intelligence provided by crime-tocrime matches, equates a DNA match to a 'resolution' and takes no account of the judicial process or criminal justice factors such as recidivism. Nonetheless it provides an estimate of the crime solving potential of an operational DNA databank.
Comparing forensic case submissions data with NZ Police figures for burglary, the high user Police Districts (A and $G$ ) submit approximately $5 \%$ of all burglary offences from their District for DNA analysis, quite a modest proportion. The low user Districts submit less than $1 \%$, while the national average is around $3 \%$. If all Districts raised submissions to the level of the high user Districts, the national clearance rate for burglary would increase by $0.5 \%$ and an annual increase in clearance of over 250 burglary offences nation-wide could be expected. If all Districts were able to raise burglary submissions to $10 \%$ of the overall number of recorded offences, and current trends were maintained, the number of resolved burglaries would increase by approximately 1000 and the national clearance rate would rise by approximately $2 \%$. Criminal justice researchers have suggested that probability and promptness of punishment can act as an effective deterrent [21] although supportive data has not been obtained in NZ [22]. Nonetheless, it is important to acknowledge the potential deterrent effect of increasing the detection rate, especially when coupled with the high prosecution rate of DNA based cases (discussed further below).

\section{Analytical Trends}

Another integral factor in the overall effectiveness of the DNA Databank is the collection and analysis of evidence. It is important that Police are kept informed of developments in DNA technology so scenes of crime officers are able to detect and appropriately recover all available types of evidence at a crime scene. Data obtained through the DIP shows noticeable differences in the submission of diverse evidence types such as samples from drinking vessels. The data also shows there is a higher than average crime-to-crime match rate for less obvious evidence types such as cigarette butts, drinking vessels, saliva stains and 'trace' DNA samples. This provides added grounds for collection and submission of such evidence and the importance of effective training to maintain awareness of such findings.

The data analysis illustrates the need for constant assessment and refinement of the DNA profiling process so the highest probability of success is afforded to evidence samples. DNA laboratories should constantly monitor the analytical success rates of evidence types, as any improvement will directly increase the number of crimes solved. For example, at current rates, an increase in the overall laboratory success rate of $5 \%$ would result in the resolution of over 120 additional crimes annually in NZ. Recent advances in DNA technology originating from the UK Forensic Science Service [23, 24] promise to have profound effects on the successful analysis of discrete levels of DNA. Pilot studies estimate that wholesale introduction of a technique known as Low Copy Number (LCN) analysis into volume crime areas such as vehicle theft would result in a net reduction in the UK crime rate of up to five percent [25]. Forensic science providers have an obligation to monitor these and other burgeoning techniques as they have unquestionable potential to aid the efforts of law enforcement agencies. The DIP framework provides a means to estimate the effect of technological modifications on the outcomes of the entire system. 


\section{Match Trends}

Recent figures from the NZ Ministry of Justice (MoJ) show that four out of five $(81 \%)$ burglars convicted in 1995 were reconvicted of an offence within two years. Over $56 \%$ were reconvicted for another property offence and $24 \%$ were reconvicted of a violent offence. Over $82 \%$ of violent offenders convicted in 1995 had prior convictions, 56\% having prior convictions for property offences (mean number of offences $=$ 5.1) [26]. These figures illustrate the known link between burglary offenders and violent offenders. A disappointing aspect of the data retrieved through the DIP was the comparatively low match rate for serious offences, such as sexual assault. The CI(BS) Act prescribes procedures for the compulsory collection of a DNA sample from any person convicted of 'a relevant offence' (offences more serious than and including entering with intent and burglary). In NZ, for violent offences and burglary alone there has been a yearly average of over 3200 sentences passed since 1995 [27] yet there are less than 4500 convicted offenders on the NDD ( $24 \%$ of total). The crime-to-person match rate for sexual assault $(26.7 \%)$ and semen samples $(27.2 \%)$ is low compared with other offence types (burglary $40.8 \%$ ). If the legislation were more diligently followed one would expect the crime-to-person match rate for serious violent offences to be noticeably higher, at least as high as $56 \%$. From the MoJ figures, only a small proportion of violent offenders (less than 18\%) are expected to be first offenders. This data suggests that failure to obtain compelled DNA Databank samples upon conviction is resulting in a reduced resolution rate for serious crimes. A primary aim for the establishment of the NZ DNA Databank was to utilise these known trends in criminal progression to solve both volume and serious crime. Underutilisation of this aspect of the CI(BS) Act may be reducing the crime-solving potential of the DNA Databank in arguably the most vital area of its intended purpose.

The CI(BS) Act specifies that match information retrieved from the DNA Databank is to be used for intelligence purposes only. In order for an individual to be prosecuted for an offence resulting from a DNA Databank match an evidential reference sample must be obtained. At present less than $10 \%$ of DNA Databank matches have resulted in the subsequent submission of an evidential sample. The low submission rate of evidential samples is due largely to an anomaly in the legislation that prevents a burglary suspect from being compelled to provide a reference sample by court order $[1,3]$. As burglaries comprise over $75 \%$ of all matches, this restricts the ability of the Crown and Police to advance DNA Databank information into the judicial process. During the next phase of development of the DIP, a facility will be added to track the number of evidential samples received, allowing cases to be followed through the judicial system.

As a pilot to this, information from fifty evidential cases was forwarded to the NZ Department for Courts to obtain the outcome of prosecution. Information was obtained from 17 cases (involving over 50 burglary charges, five sexual violations by rape and one homicide). In one case the defendant was found guilty at trial, in every other case the defendant pleaded guilty.
The overall prosecution rate for cleared offences in NZ is about $55 \%$ and of all offences prosecuted approximately $75 \%$ result in a conviction. For property offences, the prosecution and conviction rates are lower at $50 \%$ and $70 \%$ respectively [15]. For cases originating from DNA Databank evidence the conversion from cleared offences into prosecuted offences is noticeably less than published figures but this pilot research indicates the conviction rate is extremely high.

The fact that all but one of the defendants from the pilot group entered a guilty plea is also significant. Figures from the UK place the average cost of a guilty plea in magistrates' court at $£ 450$ compared with $£ 1,700$ for hearing a case before a Magistrate following a not guilty plea. For more serious cases heard in the Crown court, the disparity is more extreme ranging from $£ 2,600$ for a guilty plea to $£ 17,550$ for a not guilty hearing [28]. Assuming similar ranges apply in NZ, maintaining a high rate of guilty pleas will have substantial financial benefit for the community. This example is more relevant to Justice officials and the legislature than to law enforcement agencies but nevertheless implies that alteration to the $\mathrm{CI}(\mathrm{BS})$ Act and pursuance of DNA Databank matches will lead to the swift and cost-effective process of cases through the criminal justice system.

When applied to crime mapping, geographical information systems (GIS) study the impact of physical location of crime events. Although crime mapping in previous forms has been a valuable law enforcement tool for some time, computerised systems now mean interrogation of data at a much higher level is possible and that presentation of results is simple and easily interpreted. The findings from the DIP demonstrate that trends are evident in terms of the origin of offenders at a District level. Ultimately, and perhaps of more use, data could be interrogated at the Police station level or lower. A study from Brisbane, Australia, used spatial analysis techniques to investigate the distribution of crime across suburbs and included spatial features, such as proximity to the CBD, major roads, public transport and Police stations [17]. At all levels, trend depiction was possible, although in some cases, over-complication of maps made interpretation difficult. GIS mapping can be used to predict the location that an offender may originate from, whilst demographic information can be drawn on to help construct a 'population profile', including such aspects as age, occupation, ethnicity and prior criminal history. Clarification of the relationship between types of crimes and/or offenders and the location of a crime event will ultimately allow development of more effective crime prevention strategies. Information may also be of use to planners and policy makers, allowing the development of 'safer' suburbs and strategic commitment of resources to the DNA Databank. The next phase of the DIP intends to extend to an examination of certain demographic features of individuals involved in DNA Databank matches.

Intelligence-led policing has been embraced by international law enforcement agencies as they focus on strategies for preventing and reducing crime. It is important that forensic science too does not solely focus on retrospective analysis of criminal events, but 
looks to utilise its unique providence and expertise to maximise its impact as a tool of the criminal justice system. The preliminary outcomes of the DIP have foreshadowed a way for the utilisation of forensic DNA case data to this effect and illustrates the potential for a broad contribution to criminal justice intelligence. It also provides higher quality information to the NZ Police, placing them in a better position to oversee the use of this particular forensic tool in the investigation of crimes.

\section{References}

1 Criminal Investigations (Blood Samples) Act. 1995, Ministry of Justice: Wellington, NZ. p. 1-53.

2 Harbison SA, Hamilton JF and Walsh SJ. The New Zealand DNA Databank: Its Development and Significance as a Crime Solving Tool. Science \& Justice 2001; 41(1): 33-37.

3 Walsh SJ and De Graff G. Legal, practical and technological considerations in the application of forensic DNA profiling and the establishment of a forensic DNA database. In: Proceedings National Symposium on Forensic DNA Testing in the Administration of Justice. 2000. University of the Philippines College of Law, Diliman, Quezon City.

4 Cotton EA, Alsop RF, Guest JL, Frazier RRE, Koumi P, Callow IP, Seager A and Sparkes RL. Validation of the AMPFISTR\& SGM Plus ${ }^{\mathrm{TM}}$ System for use in Forensic Casework. Forensic Science International 2000; 112(2-3): 151-161.

5 Parson $\mathbf{W}$ and Steinlechner $\mathbf{M}$. Efficient DNA Database Laboratory Strategy for High Throughput STR Typing of Reference Samples. Forensic Science International 2001; $122: 1-6$.

6 Werret DJ. The National DNA Database. Forensic Science International 1997; 88 33-42.

7 Napper R. A National DNA Database - The United Kingdom Experience. Australian Journal of Forensic Science 2000; 32: 65-70.

8 The Future of Forensic DNA Testing: Predictions of the Research and Development Working Group. 2000, United States Department of Justice.

9 Schneider PM and Martin PD. Criminal DNA Databases: The European Situation. Forensic Science International 2001; 119: 232-238.

10 Smith A. Intelligence Led Policing; International Perspectives on Policing in the 21st Century, ed. Smith A. 1997: Lawrencevill, J : International Association of Law Enforcement Intelligence Analysts.

11 Walsh S and Moss D. Forensic DNA Databasing - Solving Crime In New Zealand Australasian Science 2001; July: 34-36.

12 Hansard. Parliamentary Mention of Proposed Amendments to Cl(BS) Act. 2001 NZPD.
13 Abaz J, Walsh SJ, Curran JM, Moss DS, Cullen JR, Bright J, Crowe GA, Cockerton SL and Power TEB. Comparison of Variables Affecting the Recovery of DNA from Common Drinking Containers. Forensic Science International 2002: 126(3); 233-40.

14 Hackett P. The Role of the DNA Database in Crime Reduction. in Proceedings DNA Forensics. 2000. Springfield, Virginia.

15 Triggs S. Crime to Sentence: Trends in Criminal Justice, 1986 to 1996. 1998, New Zealand Ministry of Justice: Wellington.

16 Ratcliffe J. Implementing and Integrating Crime Mapping into a Police Intelligence Environment. International Journal of Police Science and Management, 2000. 2(4): 313-323.

17 Murray AT, McGuffog I, Western JS and Mullins P. Exploratory Spatial Data Analysis Techniques for Examining Urban Crime. British Journal of Criminology 2001; 41(2): 309-329.

18 Ribaux $O$ and Margot $P$. Inference Structures for Crime Analysis and Intelligence: The Example of Burglary using Forensic Science Data. Forensic Science International 1999; 100: 193-210.

19 Aitken C, Connolly T, Gammerman A, Zhang G, Bailey D, Gordon R and Oldfield D. Statistical Modelling in Specific Case Analysis. Science \& Justice 1996; 36(4): 245-255

20 Crime Down - Resolutions Up. Wellington, NZ: New Zealand Police, 2001

21 Ellis RD and Ellis CS. Theories of Criminal Justice: A Critical Reappraisal. 1989 New Hampshire: Longwood Academic.

22 Triggs S. Interpreting Trends in Recorded Crime in New Zealand. 1997, New Zealand Ministry of Justice: Wellington.

23 Whitaker JP, Cotton EA and Gill P. A Comparison of the Characteristics of Profiles Produced with the AMPFISTR $\otimes S G M$ Plus ${ }^{T M}$ Multiplex System for both Standard and Low Copy Number (LCN) STR DNA analysis. Forensic Science International, 2001. 123: 215-223.

24 Gill P. Application of Low Copy Number DNA Profiling. Croatian Medical Journal, 2001; 42(3): 229-232.

25 Werret DJ and Sullivan K. The National DNA Database of England and Wales and the Strategic Use of DNA Profiling. in Proceedings The First International Conference on Forensic Human Identification in the Millennium. 1999. London.

26 Spier P. Recidivism Patterns for People Convicted in 1995. 2001, New Zealand Ministry of Justice: Wellington.

27 Spier P. Conviction and Sentencing of Offenders in New Zealand. 2000, New Zealand Ministry of Justice: Wellington.

28 Harries R. The Cost of Criminal Justice. 1999, Home Office Research, Development and Statistics Directorate: London. 